\title{
PRE-TERTIARY BLUESCHIST FACIES METAMORPHISM IN THE HELLENIDES EVIDENCED BY DETRITAL BLUE AMPHIBOLES IN THE PALEOCENE FLYSCH OF THE OTHRYS MOUNTAIN \\ K. PETRAKAKIS ${ }^{1}$, P. FAUPL ${ }^{2}$, G. MIGIROS $^{3}$, A. PAVLOPOULOS ${ }^{3}$
}

\begin{abstract}
Analyses of detrital blue amphiboles from Paleocene flysch deposits of the western Othrys Mountain show a narrow compositional variability and are comparable with published analyses from the Cycladic Islands. In contrast, analyses from Pelagonian blueschists (Olympos, Ossa, Ambelakia) show a wide compositional variation that is rather due to the lithological variability of their parental rocks and incomplete overprinting by blueschist facies metamorphism. Combined with published evidence, the above features exclude the Pelagonian rocks from being the potential source of the detrital blue amphiboles. The latter were derived from a source with "Cycladic" affinities that (1) presently is not exposed, but may have been covered tectonically during the Tertiary and (2) has been already exposed to erosion in response to subduction at the Pindos oceanic realm at the active external Pelagonian margin during Maastrichtian/Paleocene times. The data demonstrate that blueschist facies metamorphism in the Hellenides started at Pre-Tertiary times.
\end{abstract}

KEY WORDS: Hellenides, Pelagonian Zone, Othrys Mountain, Paleocene, flysch deposits, detrital blue amphiboles, "Cycladic" provenance.

\section{INTRODUCTION}

Blueschist facies metamorphic (HP/LT) rocks occur in many tectono-metamorphic units of the Hellenides (the internal Peri-Rhodopian zone, the Paikon unit of the Vardar-Axios zone and Pelagonian zone; the Cycladic Blueschist Belt; the external Phyllite-Quartzite Series). Widespread blueschist occurrences are restricted, however, to the Olympos and Ossa tectonic windows, the Pilion peninsula, southern Evia, the Cycladic islands and Samos island, and the Phyllite-Quartzite Series in Peloponess and Crete.

Despite of pre-Tertiary ages that have been suggested long time ago (Maluski et al., 1981), radiometric determinations from Cycladic rocks (59-35 Ma; see Avigad \& Garfunkel 1991) and from the external Hellenides (35-16 Ma; Seidel et al. 1982) have coined the idea in the last two decades that blueschist facies metamorphism in the Hellenides was of Tertiary age.

However, support for a pre-Tertiary onset of HP/LT metamorphism based on tectonostratigraphic and/or radiometric dating has been reported for the Paikon unit (Baroz et al., 1987), Evia (Bavay et al., 1980; Maluski et al., 1981), the Pilion peninsula (Jacobshagen \& Wallbrecher 1984), the Olympos and Ossa tectonic windows (Schermer et al., 1990), Ambelakia unit (Lips et al., 1998), the Peri-Rhodopian Zone (Michard et al., 1994), and, recently, Syros and Tinos islands (Brpcker \& Enders, 1999). These results demonstrate clearly, that HP/LT metamorphism was accompanied by intense tectonic activity within the Hellenides during the Cretaceous.

A pre-Tertiary age for the onset of HP/LT metamorphism is also supported by the occurrence of detrital blue amphiboles in Early Tertiary flysch formations in the Ionian and Pindos zones and in the western Othrys Mountain (Faupl et al., 1996, 1999). In the latter case, detrital blue amphiboles were found within Paleocene flysch deposits that lie over karstified, occasionally strongly eroded Upper Maastrichtian limestones (Richter et al., 1996a). This observation indicates that at Paleocene times some blueschist terrains were already exposed to erosion.

The present work tries to reveal the potential provenance of the detrital blue amphiboles in the Paleocene flysch deposits of the western Othrys Mountain by comparison of their chemistry with published amphibole analyses from blueschist terrains of the Hellenides. Palaeogeographic and palaeotectonic implications are discussed.

1. Institute of Petrology, University of Vienna, Althanstraße 14, A-1090 Vienna, Austria. E-mail: Konstantin.Petrakakis@univie.ac.at

2. Institute of Geology, University of Vienna, Althanstraße 14, A-1090 Vienna, Austria.E-mail: Peter.Faupl@univie.ac.at

3. Laboratory of Mineralogy-Geology, Agricultural University, Iera Odos 75, GR-11855 Athens, Greece. 


\section{GEOLOGICAL FRAMEWORK AND SAMPLING}

The Pelagonian Zone s. 1. has been subdivided into an unmetamorphosed western (Subpelagonian Zone) and a metamorphosed eastern part (Pelagonian Zone s.s.). The western and central Othrys Mountain belongs to the Subpelagonian Zone. Palaeogeographically, the Pelagonian Zone is considered to have been a micro-continental fragment bounded at its internal and external margins by the Vardar and Pindos oceans, respectively. It exhibits a complex nappe structure due to repeated thrusting and ophiolite obduction from both oceanic realms during Mid-Jurassic to early Tertiary times. This tectonic activity took place in response to subduction and ocean closure at either active side of the Pelagonian Zone that was accompanied by the formation of ophiolites, blueschist belts and final flysch deposition.

The Pelagonian Zone consists of a pre-Mid-Carboniferous metamorphic basement that is unconformably overlain by clastic Late Carboniferous-Permian sediments. The latter are transgressively overlain by a Lower Triassic volcano-sedimentary formation and a thick succession of Middle Triassic-Jurassic platform and intraplatform and marginal carbonate successions. During the Late Jurassic and Early Cretaceous, higher tectonic units, such as the Maliac nappes (basal units of the Othrys Ophiolite Complex that form the western and some parts of the central Othrys) and the Eohellenic Ophiolitic Nappe were thrust over the Pelagonian successions. After a period of extensive erosion, shallow-water limestones were deposited during the Upper Cretaceous. Generally, these limestones passed gradually into pelagic limestones and flysch sediments. However, in the western Othrys region Early Paleocene flysch deposition took place over karstified Upper Cretaceous limestones.

The heavy mineral sample was taken in a section along the road from Thavmakos to Domokos at position $\mathrm{N}$ $39^{\circ} 08^{\prime} 16^{\prime \prime}$, E $022^{\circ} 16^{\prime} 35^{\prime \prime}$ (Faupl et al. 1999). It belongs to the Paleocene flysch sediments of the western Othrys. There, the heavy mineral fraction is garnet-dominated $(>70 \%)$, containing less than $10 \%$ of the zircontourmaline-rutile-apatite association as well as very minor amounts of ophiolite-derived chrome spinel. Minor amounts $(<10 \%)$ of blue amphiboles were observed frequently.

\section{ANALYTICAL AND CALCULATION PROCEDURES}

Thirty-three detrital amphibole grains were analysed with a Cameca SX100 at the Institute of Petrology, University of Vienna. As analytical uncertainty is periodically checked to be better than $0.5 \%$ (1s) for major and minor oxides, the observed overall uncertainty (Tab. 1) is rather due to grain inhomogeneity (e.g. zoning) and varying bulk composition of the parent rocks.

Table 1: Compositional variability of detrital blue amphiboles from the Paleocene flysch deposits of the western Othrys Mountain.

\begin{tabular}{|l|c|c|c|c|c|c|c|c|c|c|c|}
\hline Wt-\% & $\mathrm{SiO}_{2}$ & $\mathrm{TiO}_{2}$ & $\mathrm{Al}_{2} \mathrm{O}_{3}$ & $\mathrm{Cr}_{2} \mathrm{O}_{3}$ & $\mathrm{FeO}$ & $\mathrm{MnO}$ & $\mathrm{MgO}$ & $\mathrm{CaO}$ & $\mathrm{Na}_{2} \mathrm{O}$ & $\mathrm{K}_{2} \mathrm{O}$ & Total \\
\hline Mean of 41 & 57.61 & 0.08 & 11.36 & 0.03 & 11.11 & 0.04 & 9.4 & 0.31 & 7.31 & 0.01 & 97.27 \\
\hline Std. Dev. & 0.95 & 0.06 & 1.12 & 0.02 & 2.54 & 0.04 & 1.46 & 0.16 & 0.16 & 0.01 & \\
\hline
\end{tabular}

For a successful discrimination of the source of the detrital blue amphiboles, measured and published analyses (a) were checked to fulfil the quality criteria for amphiboles described by Schumacher in Leake et al. (1997) and (b) were plotted into many diagrams like that of Fig. 1 by using the same model for formula recalculation. "Passed" analyses did not violate stoichiometric constrains for the maximum $\mathrm{Fe}^{3+}$-models "Sum of cations-Ca$\mathrm{Na}-\mathrm{K}=13$ " or "Sum of cations-K=15".

Factors controlling the chemical composition of blue amphiboles are $\mathrm{P}, \mathrm{T}, \mathrm{X}_{\mathrm{Fluid}}, \mathrm{f}_{\mathrm{O} 2}$ and bulk rock composition $\mathrm{X}_{\mathrm{R}}$. Fluids were excluded from consideration because ordinary microprobe analysis lacks fluid components. Regional differences in P-T- $\mathrm{O}_{\mathrm{O} 2}$ and $\mathrm{X}_{\mathrm{R}}$ are reflected in the amount of glaucophane, riebeckite, edenite and various Tschermaks-type substitutions. Various plots using the amounts of these exchange components may be useful for depicting the possible provenance of the detrital blue amphiboles.

Figure 1 shows two representative plots that depict the variation of exchange components among published analyses and measured analyses of the detrital grains. For each potential blue amphibole source as well as for the detrital blue amphiboles unique metamorphic conditions are assumed. Therefore, the variation shown for each potential source as well as for the detrital grains reflects the combined effects of analytical uncertainty, variation of bulk rock composition (i.e., different samples from the same source-region) and degree of chemical 
inhomogeneity. The latter is due to crystal zoning (that is not always explicitly documented in the literature) and incomplete overprinting relations (see below). We assume also that for all analyses treated here the analytical uncertainty is equally low and constant and corresponding to typical values assigned to microprobe analysis techniques. The combined effect of all these factors is difficult to estimate quantitatively. Nevertheless, Fig. 1 shows a rather clear positive or negative affinity of the detrital blue amphiboles towards certain potential sources.

\section{RESULTS AND DISCUSSION}

A careful inspection of the plots in Fig. 1 reveals the following: (1) Blue amphiboles from Pelagonian rocks of the Olympos and Ossa areas show a very wide variation. (2) Blue amphibole analyses from the Ampelakia unit show a narrow variation that does not coincide either with that of the detrital grains or of Cycladic sources. (3) Most Cycladic sources show a narrow compositional variation that generally coincides with that of the detrital blue amphiboles. Analyses of blue amphiboles from Pelagonian rocks of the Ossa and Olympos areas were derived from strikingly different rocks reflecting the wide lithologic range of the Pelagonian stratigraphic column. For example, blue amphiboles have been observed in many different rocks of the Ossa area (Tsangalidis, 1990). Notably, in most of them, blue amphiboles overgrew green amphiboles. Complex overgrowths of amphiboles trending from actinolite to barroisite and glaucophane/crossite yielding strongly varying, obviously disequilibium, compositions of the latter have been confirmed recently for various Pelagonian rocks from the Ossa region by M. Perraki (pers. comm.).Similarly, Schermer et al. (1990) argued that HP/LT metamorphism in the Pelagonian Zone and Ambelakia unit evolved through several tectono-metamorphic events $100 \mathrm{Ma}$ ago by overprinting
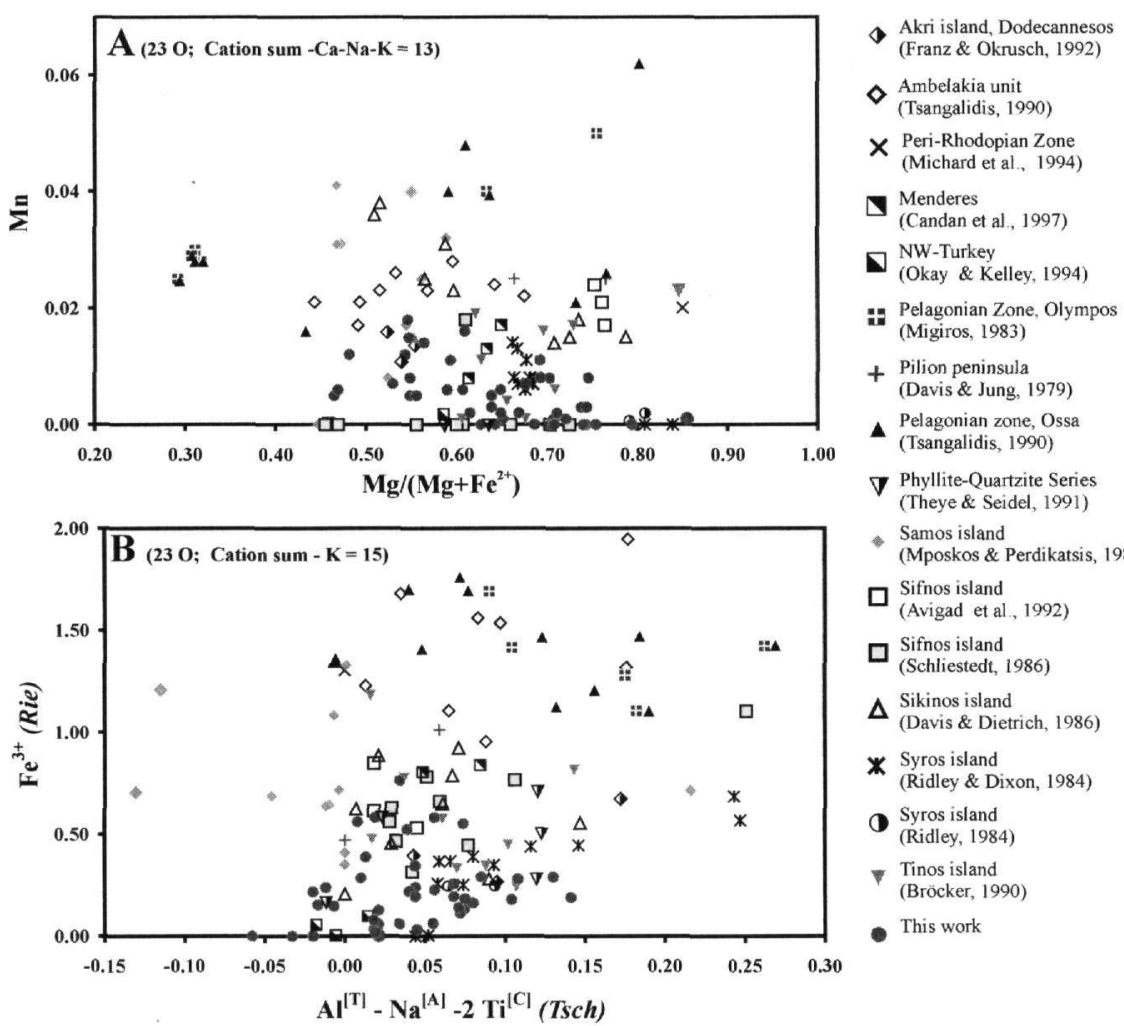

Samos island

(Mposkos \& Perdikatsis, 1984)

Sifnos island (Avigad et al., 1992)

Sifnos island

(Schliestedt, 1986)

$\Delta$ Sikinos island

(Davis \& Dietrich, 1986)

* Syros island (Ridley \& Dixon, 1984)

Syros island
(Ridley, 1984)

- Tinos island

(Bröcker, 1990)

- This work

$\mathrm{Al}^{[\mathrm{T}]}-\mathrm{Na}^{[\mathrm{A}]}-2 \mathrm{Ti}^{[\mathrm{C}]}($ Tsch $)$

Figure 1: Representative plots showing the relation of the detrital blue amphiboles with blue amphiboles from blueschist terrains of the Hellenides and adjacent areas. A: Plotted analyses are recalculated on the basis of 23 oxygens and "Sum_of_cations-K $=15$ ". B: Plotted analyses are recalculated on the basis of 23 oxygens and "Sum_of_cations-Ca-Na-K = 13". Abbreviations: $[A],[T],[C]=$ crystallographic sites in the amphibole structure $;$ Rie $=$ riebeckite component $;$ ssch $=$ Tschermak's molecule. 
early greenschist facies assemblages that still persist as relics in blue amphiboles. Such incomplete overprinting relations are indicated also for glaucophanites of the Ambelakia unit that often contain porphyroclasts of (magmatic?) perthites and relics of calcic clinopyroxenes replaced partly by crossite (Tsangalidis, 1990). The Samos blue amphibole analyses were derived from variably overprinted metagabbros that may still contain magmatic relics. These observations suggest that the HP/LT overprint was rather incomplete for each rock and/or for each amphibole grain. Thus, the large variability shown in the plots of Fig. 1 for Pelagonian rocks of the Olympos and Ossa blue amphiboles is best explained by (a) the widely varying bulk composition of the Pelagonian rocks and (b) their incomplete overprinting relations.

In contrast to this "Pelagonian" behaviour, the narrow variation of the detrital blue amphiboles suggests that the source rocks were rather more similar in terms of bulk composition; they were also better equilibrated and not strongly affected by retrograde processes and/or incomplete overprinting of earlier greenschist facies assemblages. In accordance with the references given in Fig. 1, these attributes may be assigned also to the Cycladic potential sources. Notably, the detrital blue amphiboles overlap with Cycladic potential sources; they do not overlap with blue amphiboles of the Ambelakia unit, which, in contrast to the Pelagonian sources, show a narrow compositional variation.

However, the compositional similarity of the detrital blue amphiboles with those from the Cycladic Islands does not necessarily imply that the former were derived directly from any of these islands. It suggests that the source rocks were "Cycladic" (i.e. exhibiting the paragenetic, textural and chemical features matching the rocks of Cycladic Islands), rather than Pelagonian. The exclusion of a Pelagonian source agrees well with numerous observations that the Pelagonian rocks in the Olympos-Ossa-Pilion region underwent incomplete recrystallization under HP/LT conditions as early as the Lutetian. Derycke \& Godfrieux (1979) reported, for example, that Upper Cretaceous to Mid Eocene limestones and flysch successions in the Olympos region were affected by HP/ LT metamorphism. Wallbrecher (1983) noted that rocks of the transgressive Upper Cretaceous and of the overlying early Tertiary ophiolite nappes of the southern Pilion peninsula and Sporades islands contain blue amphiboles. Schermer et al. (1990) pointed out that thrusting of the stacked Pelagonian (Pierien and Infrapierien units) and Ambelakia units over the autochthonous Olympos carbonates took place under still prevailing HP/ LT conditions in late Eocene times (40-36 Ma). Obviously, these Pelagonian rocks could not have been providing detrital blue amphiboles into the Paleocene flysch sediments of the western Othrys Mountain and, therefore, can be excluded as potential sources.

The "Cycladic" source of the detrital blue amphiboles is presently not exposed in the neighbourhood of the Othrys Mountain. However, it cannot be excluded that the detrital blue amphiboles were transported over large distances along orogen-parallel structures into the Paleocene flysch basin of the western Othrys Mountain. Irrespective of its exact palaeogeographic position, we suggest that this "Cycladic" blueschist source was located near the external (currently western) Pelagonian margin. Its formation may be ascribed to the subduction of the Pindos Ocean (Faupl et al. 1999). The detrital blue amphiboles in question demonstrate that HP/LT metamorphism was active at Pre-Tertiary times. This is consistent with the radiometric age determinations stated earlier.

\section{CONCLUSIONS}

As detrital blue amphiboles are frequent in the Paleocene flysch deposits of the western Othrys Mountain, but completely missing farther to the east of the Pelagonian Zone (Faupl et al. 1999), we suggest that the "Cycladic" blueschist source terrain was (1) located near the external (currently western) margin of the Pelagonian microcontinent, (2) formed and then tectonically exhumed in response to subduction of the Pindos Ocean and (3) the Cycladic blueschists, their northward continuation (southern Evia, Pilion peninsula and blueschist in the Ossa and Olympos tectonic windows) and the "Cycladic" source of the detrital blue amphiboles were "extruded" slices of HP/LT rocks from one or more orogenic wedges that were active during the Cretaceous (Grasemann et al., 1998). The "Cycladic" source is currently not exposed in the neighbourhood of the western Othrys Mountain because it either has been completely eroded or, most probably, tectonically covered during Tertiary tectonic activity. Thus, the current western tectonic boundary of the Pelagonian Zone should not be confused with the active, external margin of the Pelagonian micro-continent during the Cretaceous and Paleocene.

The occurrence of detrital blue amphiboles in the Paleocene flysch deposits of the western Othrys Mountain is consistent with the radiometric age determinations referred earlier; they demonstrates clearly, that HP/LT metamorphism in the "Cycladic" source terrain was active as late as the Maastrichtian. They also suggest that the earliest exhumation and erosion of "Cycladic" blueschists took place as late as the Maastrichtian/Paleocene. A lower age limit for exhumation and erosion of "Cycladic" blueschists is constrained by the absence of detrital blue amphiboles in the Turonian turbidites of the "First Pindos Flysch" (Faupl et al., 1998). 
The detrital blue amphiboles in question, the Turonian turbidites of the "First Pindos Flysch" and the Lower Cretaceous and Turonian turbidites of the Beotian Trough (Richter et al., 1996b,c) demonstrate that during the Cretaceous the external margin of the Pelagonian micro-continent, as well as the adjacent external areas (Pindos and Beotian basins), were sites of "Cycladic"-type blueschist facies metamorphism, intense tectonic activity and blueschists exhumation in response to the subduction of the Pindos Ocean.

\section{ACKNOWLEDGMENTS}

The authorities of the University of Vienna and of the Agricultural University of Athens are acknowledged for financial support. Th. Ntaflos, Vienna, for providing a perfectly working microprobe and valuable analytical support. E. Mposkos and an anonymous reviewer are acknowledged for critical comments and discussions.

\section{REFERENCES}

AVIGAD D \& GARFUNKEL Z (1991) Uplift and exhumation of high-pressure metamorphic terrains: the example of the Cycladic blueschist belt (Aegean Sea). Tectonophysics 86: 159-196

AVIGAD D, MATTHEWS A, EVANS B, GARFUNKEL Z (1992) Cooling during the exhumation of a blueschist terrane, Sifnos (Cyclades), Greece. Eur J Mineral 4: 619-634

BAROZ F, BEBIEN, J, IKENNE M (1987) An example of high-pressure low-temperature metamorphic rocks from an island-arc: the Paikon Series (Innermost Hellenides, Greece). J Metamorphic Geol 5: 509-527

BAVAY D, BAVAY P, MALUSKI H, VERGÉLY P, KATSIKATSOS G (1980) Datation par la méthode ${ }^{40} \mathrm{Ar} /{ }^{39} \mathrm{Ar}$ de minéraux de métamorphisms de haute pression en Eubée de sud (Gréce) Corrélation avec les évènements tectonométamorphiques des Hellenides internes. C R Acad Sci Paris 209: 1051-1054

BRÖCKER M (1990) Die metamorphe vulkanosedimentäre Abfolge der Insel Tinos. Geotekt Forsch 74: 1-98

BRÖCKER M, ENDERS M (1999) U-Pb zircon geochronology of unusual eclogite-facies rocks from Syros and Tinos (Cyclades, Greece). Geol Mag 136: 111-118

DAVIS E N, DIETRICH V J (1986) Petrologie und Geochemie des Kristallins von Sikinos (Südliche Kykladen). IGME, Inst Geol Geoph Res Special Issue 47-71 Athens

DAVIS E N, JUNG D (1979) Metamorphe Fazies und Geochemie der Glaukophangesteine von Pilion. Proc Acad Athens 53: 537-553 Athens

DERYCKE J F, GODFRIAUX I (1979) A cross section in the Olympus area, Thessaly, Greece. Proc VI Colloq Aegean Regions Athens 1977/1: 353-354

FAUPL P, PAVLOPOULOS A, WAGREICH M, MIGIROS G (1996) Pre-Tertiary blueschist terrains in the Hellenides: evidence from detrital minerals of flysch successions. Terra Nova 8: 186-190

FAUPL P, PAVLOPOULOS A, MIGIROS G (1998) On the provenance of flysch deposits in the External Hellenides of mainland Greece: results from heavy mineral studies. Geol Mag 135: 421-442

FAUPL P, PAVLOPOULOS A, MIGIROS G (1999) The Palaeogene history of the Pelagonian Zone s.l. (Hellenides, Greece) Heavy mineral study from terrigenous flysch sediments. Geologica Carpathica 50: 449-458

FRANZ L, OKRUSCH M (1992) Aragonite-bearing blueschists on Akri island, Dodecanese, Greece. Eur J Mineral 4: 527-537

GRASEMANN B, RATSCHBACHER L, HACKER BR (1998) Exhumation of ultrahigh-pressure rocks : thermal boundary conditions and cooling history. In : Hacker BR, Liou JG (eds) When Continents Collide: Geodynamics and Geochemistry of Ultrahigh-Pressure Rocks. Kluwer Acad Press, pp 117-139

JACOBSHAGEN V, WALLBRECHER E (1984) Pre-Neogene nappe structure and metamorphism of the Northern Sporades and the southern Pilion peninsula. In: Dixon J E, Robertson A H F (eds) The geological evolution of the Eastern Mediterranean. Blackwell Scientific Publications Oxford, pp 591-602

LEAKE B E (chairman) et al (1997) Nomenclature of amphiboles: Report of the Subcommittee on Amphiboles of the International Mineralogical Association, Commission on New Minerals and Mineral Names. Amer Mineral 82: 1019-1037

LIPS A L W, WHITE S H, WIJBRANS J R (1998) ${ }^{40} \mathrm{Ar} /{ }^{39} \mathrm{Ar}$ laserprobe direct dating of discrete deformational events: a continuous record of early Alpine tectonics in the Pelagonian Zone, NW Aegean area, Greece. Tectonophysics 298: 133-153

MALUSKI H, VERGÉLY P, BAVAY D, BAVAY PH, KATSIKATSOS G $(1981){ }^{40} \mathrm{Ar} /{ }^{39} \mathrm{Ar}$ dating of glaucophanes and phengites in southern Euboea (Greece) geodynamic implications. Bull Soc Geol France (VII) 23: 469-476

MICHARD A, GOFFÉ B, LIATI A, MOUNTRAKIS D (1994) Découverte du faciés schiste blue dans le nappes du Circum-Rhodope: un élément d' une ceinture HP-BT éohellénique en Grèce septentrionale? CR Acad Sci 
Paris série II 318: 1535-1542

MIGIROS G (1983) Geological investigation of the area of Lower Olymp, Thessaly. PhD Thesis, Geology Department, University of Patras (in Greek)

MPOSKOS E, PERDIKATSIS V (1984) Petrology of glaucophane metagabbros and related rocks from Samos, Aegean Island (Greece). N Jb Miner Abh 149: 43-63

RICHTER D, M1/4LLER C, RISCH H (1996a) Die Flysch-Zonen Griechenlands XI: Neue Daten zur Stratigraphie und Paläogeographie des Flysches und seiner Unterlage in der Pelagonischen Zone (Griechenland). $\mathrm{N} \mathrm{Jb} \mathrm{Geol}$ Paläont Abh 201: 327-366

RICHTER D, M1/4LLER C, MIHM A, RISCH H (1996b) Die Flysch-Zonen Griechenlands XII: Das Böotikum und seine Flysche im Bereich des Iti-Parnass-Elikon-Gebirges, des nordwestlichen Kallidromon-Gebirges und des südwestlichen Othrys-Gebirges (Mittelgriechenland). N Jb Geol Paläont Abh 201: 367-409

RICHTER D, MIHM A, M1/4LLER C (1996c) Die Flysch-Zonen Griechenlands XIV: Der Böotische Flysch im Gerania-Gebirge (Mittelgriechenland). N Jb Geol Paläont Abh 201 : 421-432

RIDLEY J (1984) Evidence of a temperature-dependent 'blueschist' to 'eclogite' transformation in high-pressure metamorphism of metabasic rocks. Jour Petrol 25: 852-870

RIDLEY J, DIXON J E (1984) Reaction pathways during the progressive deformation of a blueschist metabasite: the role of chemical disequilibrium and restricted range equilibrium. Jour metamorphic Geol 2: 115-128

SCHERMER E R, LUX D R, BURCHFIEL B C (1990) Temperature-time history of subducted continental crust, Mount Olympos region, Greece. Tectonics, 9: 1165-1195

SCHLIESTEDT M (1986) Eclogite-blueschist relationships as evidenced by mineral equilibria in high-pressure metabasic rocks of Sifnos (Cycladic Islands), Greece. Jour Petrol 27: 1437-1459

SEIDEL E, KREUZER H, HARRE W (1982) A Late Oligocene/Early Miocene high-pressure belt in the external Hellenides. Geol $\mathrm{Jb}$ 23: 165-206

THEYE T, SEIDEL E (1991) Petrology of low-grade high-pressure metapelites from the External Hellenides (Crete, Peloponnese) A case study with attention to sodic minerals. Eur J Mineral 3: 343-366

TSANGALIDIS A K (1990) Petrologic study of the Ossa-Region, Thessaly. PhD-Thesis Agricultural University of Athens, pp 1-385 (in Greek)

WALLBRECHER E (1983) Alpidischer Deckenbau und Metamorphose auf den Nord-Sporaden und auf der südlichen Pelion-Halbinsel (Thessalien, Griechenland). Berliner geowiss Abh 48: 99-116 